\title{
The Effect of Synectic Learning Model and Learning Interests on Creative Thinking Ability in Writing Free Poetry for Class V Students of SD Negeri 112320 Aek Kota Batu
}

\author{
Desi Susanty ${ }^{1}$, Abdurahman Adisaputera ${ }^{2}$, Anita Yus ${ }^{3}$ \\ ${ }^{1}$ Postgraduate Program in Universitas Negeri Medan, Indonesia \\ ${ }^{2,3}$ Universitas Negeri Medan, Indonesia \\ Desisusanty728@gmail.com
}

\section{Abstract}

This study aims to determine: (1) To determine the differences in students' creative thinking skills in writing free poetry between students who are taught with the synectic learning model compared to the reciprocal learning model; (2) To determine the differences in students' creative thinking skills in writing free poetry between students who have high learning interest compared to low learning interest; and (3) to determine the interaction between learning models and interest in learning in influencing students' creative thinking abilities in writing free poetry. This research was conducted at SDN 112320 Aek Kota Batu. The research method used is a quantitative method with a $2 \times 2$ experimental design. Data collection techniques used questionnaires and tests. The data analysis technique in this study used the Two Way Anova test. The results showed that: (1) There is a significant difference in the average creative thinking ability of students who are taught with the synectic model compared with the average thinking ability of students taught with the reciprocal model (Fcount $=11.664$ and sig. $0.001<0.05)$; (2) The average creative thinking ability of students who have high learning interest is higher than the average creative thinking ability of students who have low learning interest (Fcount $=12.165$ and sig. $0.001<0.05)$; and (3) There is an interaction between learning models and interest in learning in influencing students' creative thinking abilities $($ Fcount $=7.054$ and sig. $0.011<0.05)$.
Keywords

synectic model; reciprocal model of learning interests; creative thinking

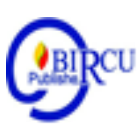

\section{Introduction}

Indonesian subjects taught in elementary schools include several aspects including speaking, listening, reading, and writing. Each skill has a close relationship with one another. This is reinforced by Syarif (2009: 1) who states that listening and reading skills are considered receptive abilities. Meanwhile, speaking and writing skills are called productive abilities. In addition, Anggraeni (2017: 2) explains that writing is a language skill that is most recently mastered after listening, speaking, and reading skills. Like speaking, writing is an attempt to express the thoughts and feelings that exist in a language speaker. The difference lies in the way in which it is expressed. Thoughts and feelings in speaking are expressed orally, while in writing it is done in writing. The reasoning skills certainly influenced writing skills because writing is a very complex skill for students that cause them not to have the ability to write well, as well as writing explanatory texts (Saragih, 2019). 
In writing activities, students can appreciate feelings with a poem which is not only intended for appreciation and understanding, but has the effect of sharpening the sensitivity of feelings, reasoning, and children's sensitivity to human problems. This ability is determined by several important factors. In addition to applying the right models, methods and strategies, what really determines is the teacher's role in the learning process. Therefore the teaching method can affect the process and student learning outcomes (Yusrizal \& Fatmawati, 2020). Poor teacher teaching methods will have an impact on the poor learning outcomes obtained by students. Steps that can be taken to improve students 'creative thinking skills in writing free poetry is to make improvements, namely by using a learning model that can increase students' creativity in writing. Writing skills are one of the activities that need to be done to foster the ability to write (Nazila, 2020).

There are several learning models that can improve students' ability to write free poetry, some of which are the synectic learning model and the reciprocal learning model. The synectic model is a learning model that can develop in the process of learning to think creatively in writing free poetry that starts with describing situations related to visualization and feelings, analogy to being able to re-examine the tasks that have been done. This synectic model can also give students the freedom to think creatively which leads students to be able to think through a flow that is in accordance with the pattern of child development from elementary to high level. In line with that, Gordon (in Joyce, 2011: 34) states that this synectic learning model is very suitable to be applied to elementary school (SD) and junior high school (SMP) education.

The reciprocal model is a model used to help students focus on what they are reading and make students understand what they read (Efendi, 2013: 86). The strengths of the reciprocal model according to Shoimin (2014: 154) are: (1) training students' ability to learn independently so that their ability to learn independently can be improved; (2) train students to re-explain the material being studied to other parties. Thus, the application of this learning can be used by students in presenting their ideas; and (3) learning orientation is investigation and discovery. In addition to the learning model, there are other factors such as student interest in learning that can also affect student learning outcomes (Yusrizal et al, 2019). Learning interest is an individual tendency to have a sense of pleasure without coercion so that it can cause changes in knowledge, skills and behavior (Yusrizal et al., 2019).

\section{Review of Literatures}

\subsection{Synectic Learning Model}

The synectic model is an interesting approach to increasing creativity. This synectic model is oriented towards improving problem-solving abilities and developing student creativity. Thus, students will realize that there are various perceptions of each individual so that they can respect each other and can solve a problem or idea. The opinion above is in accordance with that expressed by Joyce (2011: 34) which states that the synectic learning model is a learning process designed to help teachers solve problems and write various activities, as well as gain new perspectives in making topics from various fields.

Based on the concept of the synectic learning model, this model emphasizes the process of extracting meaningful ideas in order to increase creative activity through training so that students' creativity will develop and can be utilized in real life. Gordon also reveals that the specific processes in synectics are developed from a set of basic assumptions about the psychology of creativity. 
Meanwhile according to Shaddiqui (2013: 132) this synectic model is a model that enhances individual and group creativity to make students able to learn about their classmates by understanding their ideas and problems, to encourage and support weak students, to develop self-confidence. students, to develop students' self-awareness, to be used in all areas of the curriculum, to encourage the best discussion among teachers and students, to increase creativity, to explore social problems, to develop problem-solving approaches to student behavior, to help students to design or products, and to broaden our perspective of the concept. The synectic learning model consists of six stages, namely (1) describing the current situation (2) direct analogy (3) personal analogy (4) solid conflict (5) direct analogy (6) re-examining the initial task.

According to Mutmainah (2016) in her journal, she classified the advantages of the synectic model as follows: (1) this model is useful for developing new understanding in students about a problem, so that they are aware of how to behave in certain situations; (2) can develop clarity of understanding and internalization in students about new material; (3) can develop creative thinking, both in students and teachers; (4) this model is implemented in an atmosphere of intellectual freedom and equal dignity between students; (5) this model helps students find new ways of thinking in solving a problem.

Meanwhile, the drawbacks are (1) difficult for teachers and students who are familiar with using the old method which emphasizes the delivery of information; (2) this model focuses on reflective and imaginative thinking in certain situations, so it is likely that students do not master facts and implementation procedures or skills; and (3) inadequate educational facilities and infrastructure in schools.

\subsection{Reciprocal Learning Model}

According to Widiya (2011) reciprocal is a teaching procedure or approach designed to teach students about cognitive strategies and to help students understand reading well. Meanwhile, according to Efendi (2013: 86); Reciprocal learning is used to help students focus on what they are reading and make students understand their reading. According to Trianto (2014: 191) Reciprocal is an approach to teaching students learning strategies. Reciprocal was developed to help teachers to use collaborative learning dialogues to teach reading comprehension independently in the classroom. The use of this approach was chosen for several reasons, including: (1) it is an activity that readers routinely use; (2) improve understanding and provide reading opportunities for selfmonitoring; and (3) strongly supports cooperative dialogue (discussion).

According to Palinscar (in Shoimin, 2014: 153) Reciprocal contains four strategies; (1) Generating question; (2). Clarifing; (3) predieting; and (4) summarizing. The strengths of the reciprocal model according to Shoimin (2014: 154) are: (1) training students' ability to learn independently so that their ability to learn independently can be improved; (2) train students to re-explain the material being studied to other parties. Thus, the application of this learning can be used by students in presenting their ideas; and (3) learning orientation is investigation and discovery. By finding and investigating the concepts being discussed by them, students find it easier to remember a concept. The understanding of students in a concept is also an understanding that is really understood by students. So, reciprocal is a learning model in which students are given the opportunity to study the material first. Then, students explain the material being studied again to other students. The teacher only acts as a facilitator and guide in learning, namely to straighten or provide an explanation of material that cannot be solved independently by students. If the reciprocal model is used properly by the teacher, it can improve student learning outcomes (Yusrizal et al., 2019). 


\subsection{Interest in Learning}

Interest is a feeling of interest, attention, more desire that a person has for something, without any encouragement. This interest will stay and develop in him to get support from his environment in the form of experience (Yusrizal et al., 2019). According to Slameto (2010:180) interest is a constant tendency to pay attention to and remember some activities. Meanwhile, according to Djaali (2008: 121) interest is a sense of preference and a sense of interest in something or an activity, without being asked. Crow \& C row (in Djaali, 2008: 121) says that "interest is related to the style of motion that encourages a person to face or deal with people, objects, activities, experiences stimulated by the activity itself". Meanwhile, learning is a change in students in the form of knowledge, skills and behavior as a result of interaction with their environment. Thus it is concluded that the notion of interest in learning is the tendency of individuals to have a sense of pleasure without coercion so that it can cause changes in knowledge, skills and behavior.

\subsection{Students' Creative Thinking}

When someone writes poetry, there are a series of creative thinking activities that a writer must go through, in their own way and style. As for the first creative process, the writer finds an idea or inspiration, the second writer contemplates an object so that the idea is interesting, the three authors pour the ideas that have been contemplated in the form of a written outline, the four authors make improvements or revisions to the framework that has been made. In this regard, it is strengthened and explained according to Sutardi (2012: 39) saying that writing poetry will definitely go through a series of highly individual creative activities. This means that each individual has their own way and style of writing poetry. This is individual, but there is a generalization of the creative process as well as when writing poetry which consists of four stages. The four stages are as follows:

1. Idea Search

First in writing is an idea. There are also those who mention inspiration, which is something that touches the taste or soul that makes someone want to devote and express it in poetry.

2. Sedimentation or contemplation

If the idea has been obtained then contemplates it or contemplates it, this process is called idea maturation. Ideas are raw material, before they are written they need to be matured, and the way is by seduction in contemplation or contemplation.

3. Writing

If the process of settling or contemplating an idea is ripe then write it down. Don't wait for time. Write down what you want to write immediately.

4. Editing and revision

This editing is related to correcting the poetry that was created in the language aspect, whether it is writing errors, changing words, to sentences, even writing system. Meanwhile, revision is related to changing the content or substance. These two things must have happened in every poetry creation. 


\section{Research Methods}

This type of research is an experiment with a $2 \times 2$ factorial design. This research was conducted at SD Negeri 112320 Aek Kota Batu. The population in this study were all students of SD Negeri 112320 Aek Kota Batu in the academic year 2020/2021, while the sample in this study were students of class $\mathrm{V}$ as many as 46 students in 2 classes, namely $\mathrm{V} / \mathrm{a}$ as many as 23 students and class IV / b as many as 23 students. The data collection techniques used in this study was questionnaires and tests. The data analysis technique used in this research is inferential statistical techniques. Hypothesis testing is done by using the Two Way Anova test with a significant level of 0.05. Before the Two Way Anova test is carried out, first the analysis requirements test is carried out, namely the normality test and the homogeneity test of the data. The normality test was performed using the Shapiro-Wilk test, while the data homogeneity test was carried out by the Levene test with a significant level of 0.05 .

\section{Research Results and Discussion}

\subsection{Results}

\section{a. Data Description}

1. Creative Thinking Ability in Writing Student's Free Poetry Taught with Synectic Learning Model

From the results of statistical calculations, it is known that the creative thinking skills of students who are taught with the synectic learning model get the lowest score, namely 75 , and the highest score, 95 with an average of 85.43 ; the variant is 33.89 and the standard deviation is 5.82. The frequency distribution score of the ability to think creatively students taught by synectic learning model presented in the image below it.

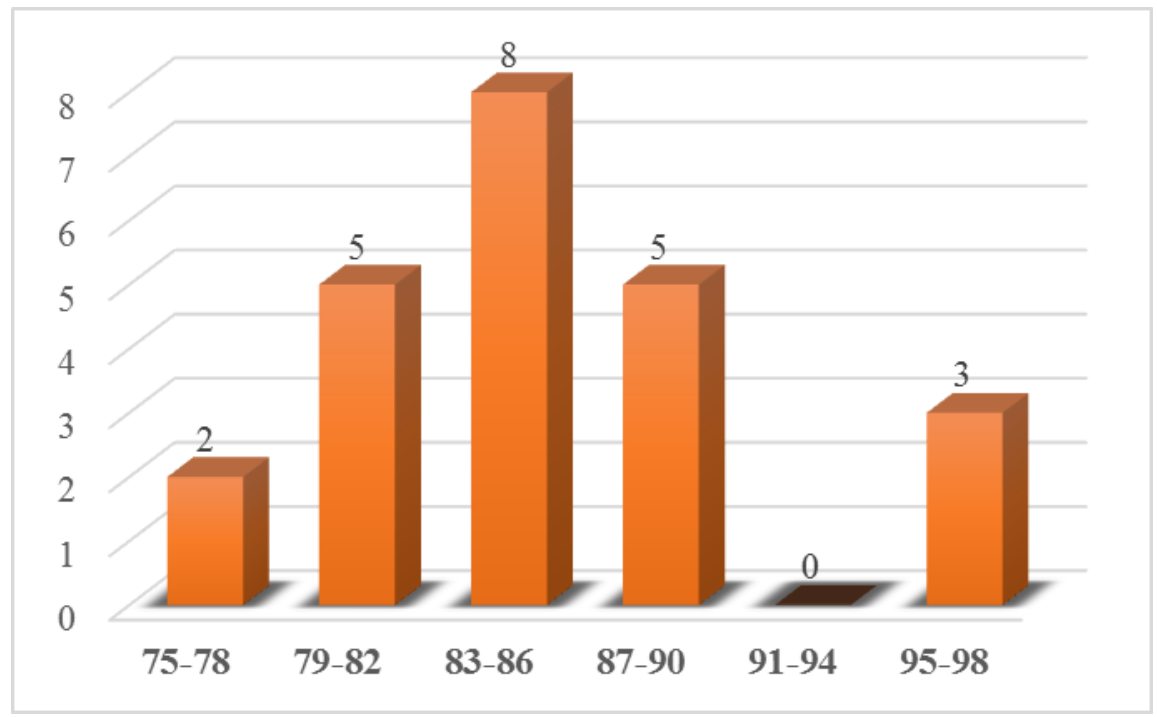

Figure 1. Histogram of Students' Creative Thinking Ability Taught with Synectic Learning Model

From this it is clear that the creative thinking abilities of students who are taught with the synectic learning model have the highest number of frequencies in the 83-86 interval class, while the least number of frequencies is in the 91-94 interval class. 
2. Students' Creative Thinking Ability Taught with Reciprocal Learning Model

From the results of statistical calculations it is known that the creative thinking skills of students who are taught with the reciprocal learning model get the lowest score, namely 60, and the highest score is 90, with an average of 78.26; the variant is 67.29 and the standard deviation is 8.20. The frequency distribution of students' creative thinking skills scores taught by the reciprocal learning model is presented in the following figure.

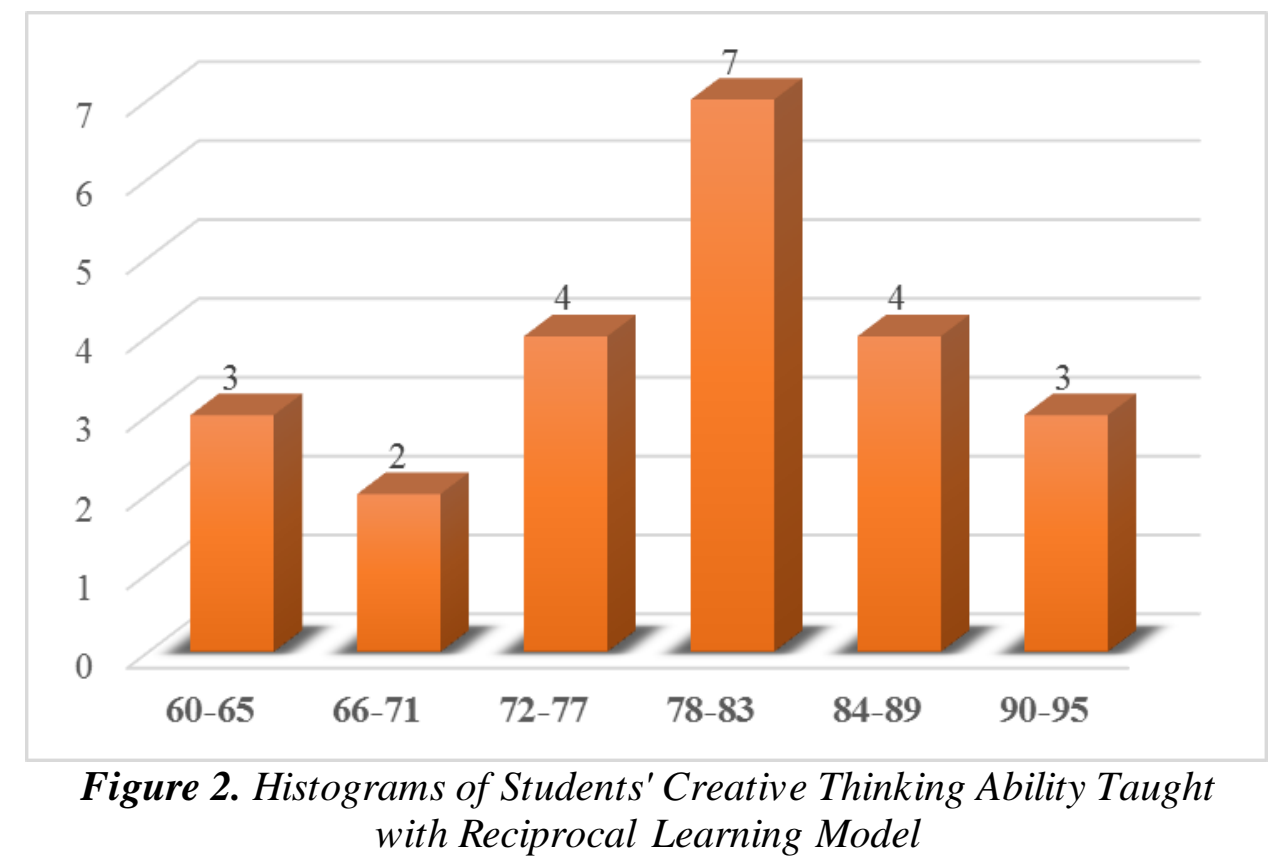

From the pictures it is evident that the creative thinking abilities of students taught using learning model reciprocal number of the most frequent were the class interval 7883 , while the number of frequencies which at least is in a class interval 66-71.

b. Prerequisite Test

1. Normality Test

Table 1. Tests of Normality

\begin{tabular}{|l|r|r|r|r|r|r|}
\hline & \multicolumn{3}{|c|}{ Kolmogorov-Smirnov a } & \multicolumn{3}{c|}{ Shapiro-Wilk } \\
\cline { 2 - 7 } & Statistics & \multicolumn{1}{c|}{ df } & \multicolumn{1}{c|}{ Sig. } & \multicolumn{1}{c|}{ Statistics } & \multicolumn{1}{c|}{ df } & \multicolumn{1}{c|}{ Sig. } \\
\hline $\begin{array}{l}\text { Standardized Residual } \\
\text { for Student_ability }\end{array}$ &, 115 & 46 &, 161 &, 966 & 46 &, 201 \\
\hline
\end{tabular}

a. Lilliefors Significance Correction

Based on the table above, the results of the normality test of the research data obtained a sig value of $0,201>0.05$, thus it can be concluded that the research data were normally distributed. 
2. Homogeneity Test

Table 2. Levene's Test of Equality of Error Variances

Dependent Variable: Students' Creative Thinking Ability

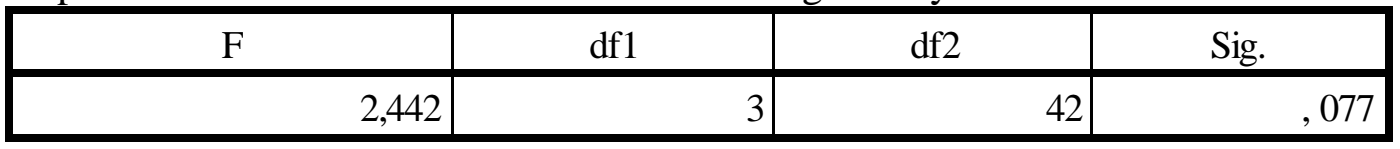

Based on the table above shows that the homogeneity test of the research data obtained the sig value of $0,077>0.05$, thus it can be concluded that the research data group is relatively the same or is homogeneous.

\section{c. Hypothesis Test}

This research hypothesis testing using two-way ANOVA with $2 \times 2$ factorial. Hypothesis testing data can be seen in the following table:

Table 3. SPSS Output Two Way Anova Calculation Tests of Between-Subjects Effects

Dependent Variable: Students' Creative Thinking Ability

\begin{tabular}{|l|r|r|r|r|r|}
\hline Source & $\begin{array}{r}\text { Type III Sum of } \\
\text { Squares }\end{array}$ & df & Mean Square & \multicolumn{1}{c|}{ F } & \multicolumn{1}{c|}{ Sig. } \\
\hline Corrected Model & 1092,439 a & 3 & 364,146 & 8,864 &, 000 \\
Intercept & 297098,248 & 1 & 297098,248 & 7231,617 &, 000 \\
Learning model & 479,189 & 1 & 479,189 & 11,664 &, 001 \\
Interest to learn & 499,765 & 1 & 499,765 & 12,165 &, 001 \\
Learning_Model * Learning & 353,970 & 1 & 353,970 & 7,054 &, 011 \\
Interest & 1725,496 & 42 & 41,083 & & \\
Error & 310975,000 & 46 & & & \\
Total & 2817,935 & 45 & & & \\
Corrected Total & & & & \\
\hline
\end{tabular}

a. $\mathrm{R}$ Squared $=, 388$ (Adjusted R Squared =, 344)

Table 4. Comparison of Creative Thinking Abilities Based on Learning Models Dependent Variable: Ability to Think Creative

\begin{tabular}{|l|r|r|r|r|}
\hline & & & \multicolumn{2}{|c|}{$95 \%$ Confidence Interval } \\
\cline { 4 - 5 } Learning Model & Mean & Std. Error & Lower Bound & Upper Bound \\
\hline Synectic Learning Model & 84,663 & 1,369 & 81,899 & 87,426 \\
Reciprocal Learning Model & 78,125 & 1,338 & 75,425 & 80,825 \\
\hline
\end{tabular}

Table 5. Comparison of Creative Thinking Ability Based on Level of Learning Interest Depen dent Variable: Ability to Think Creative

\begin{tabular}{|l|r|r|r|r|}
\hline & & \multirow{2}{*}{ Mn\% Confidence Interval } \\
\cline { 4 - 5 } Interest in Learning & Mean & Std. Error & Lower Bound & Upper Bound \\
\hline High & 84,732 & 1,261 & 82,188 & 87,276 \\
Low & 78,056 & 1,440 & 75,149 & 80,963 \\
\hline
\end{tabular}


1. First Hypothesis

Ho: $\mu \mathrm{A}_{1}=\mu \mathrm{A}_{2}$

Ha: $\mu \mathrm{A}_{1} \neq \mu \mathrm{A}_{2}$

Based on the SPSS output that appears from the results of the two-way ANOVA calculation in Table 1, it is found that the ciuluad $\mathrm{F}$ value in the learning model is 11.664 with a significant $0.001<0.05$, this indicates that there is a significant difference between the average creative thinking ability in writing free poetry of students taught with a synectic model compared to a reciprocal learning model Furthermore, based on the SPSS output in Table 2 , the average ability to think creatively in writing free poetry of students taught using the synectic model is 84.663. Meanwhile, the average of students' ability to think creatively in writing free poetry taught by direct leaming was 78.125. So that the hypothesis testing rejects ${ }_{\text {н力 }}$ and accepts $\mathrm{H}_{\mathrm{a}}$ Thus, itcan be concluded that there are differences instudents' creative thinking abilities in writing free poetrybetween students who are taught with the synectic model compared to the reciprocal leaming model.

\section{Second Hypothesis}

Ho $: \mu \mathrm{B}_{1} \leq \mu \mathrm{B}_{2}$

Ha: $\mu \mathrm{B}_{1}>\mu \mathrm{B}_{2}$

Based on the SPSS output of ANAVA calculation results in Table 1, it is found that the value of $\mathrm{F}_{\text {oum }}=12.165$ with a significant amount of $0.001<0.05$, this indicates that there is a significant difference between the average creative thinking ability in writing free poetry of students who have an interest learning is high compared to students who have low learning interest. Furthermore, based on the SPSS output in Table 3, the average creative thinking ability in writing free poetry of students who have high learning interest is 84.732. Meanwhile, the average creative thinking ability of students who have low leaming interest is 78.056 . So that the hypothesis testing rejects ${ }_{\mathrm{r}}$ and accepts $\mathrm{H}_{\mathrm{a}}$. Thus, itcan be concluded that the average creative thinking ability of students who have high learning interest is higher than students who have low leaming interest.

\section{Third Hypothesis}

Ho: $\mathrm{A} \times \mathrm{B}=0$

Ha: $\mathrm{A} \times \mathrm{B} \neq 0$

Based on the SPSS output, the ANOVA calculation results in Table 1, it is found that $\mathrm{F}_{\text {coum }}=7.054$ and $a$ significant value of 0.011 . So it can be seen that the significant value is $0.011<0.05$ so that the hypothesis testing rejects $\mathrm{H}_{\mathrm{o}}$ and accepts $\mathrm{H}_{\mathrm{a}}$ Thus it can be concluded that there is an interaction between learning models and interest in learning in influencing students' creative thinking skills in writing free poetry in writing free poetry. The interaction of leaming models and interest in learning in influencing students' creative thinking skills in writing free poetry can be seen in the following figure. 


\section{Estimad Marginal of Creative Thinking Ability}

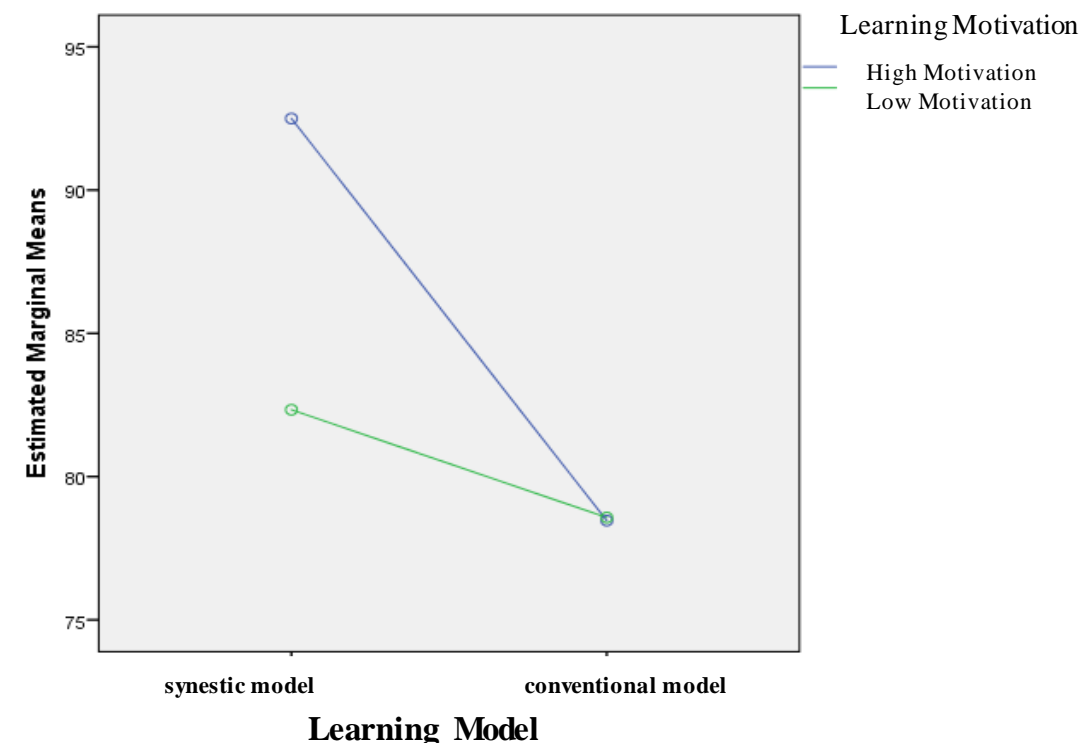

Figure 3. Interaction Model of Learning and Interest in Learning in Affects Ability of Creative Thinking in Writing Poetry Free

\section{d. Tukey's Test}

After the hypothesis test is carried out, it is necessary to carry out further tests, namely by using Post Hoc with Tukey's test, the results are presented in the following table.

Table 6. SPSS Output Tukey Test Results

\section{Multiple Comparis ons}

Dependent Variable: Students' Abilities

Tukey HSD

\begin{tabular}{|c|c|c|c|c|c|c|}
\hline \multirow[b]{2}{*}{ (I) Group } & \multirow[b]{2}{*}{ (J) Group } & \multirow{2}{*}{$\begin{array}{c}\text { Mean } \\
\text { Difference } \\
\text { (IJ) }\end{array}$} & \multirow[b]{2}{*}{ Std. Error } & \multirow[b]{2}{*}{ Sig. } & \multicolumn{2}{|c|}{$\begin{array}{l}\text { 95\% Confidence } \\
\text { Interval }\end{array}$} \\
\hline & & & & & $\begin{array}{l}\text { Lower } \\
\text { Bound }\end{array}$ & $\begin{array}{l}\text { Upper } \\
\text { Bound }\end{array}$ \\
\hline \multirow{3}{*}{$\begin{array}{l}\text { Synectic- } \\
\text { High MB }\end{array}$} & Synectic- Low MB & 7,103 & 2,738 &, 060 &,- 22 & 14.43 \\
\hline & Reciprocal-High MB & $6,964 *$ & 2,522 &, 041 &, 22 & 13.71 \\
\hline & Reciprocal-Low MB & 13,214 * & 2,583 &, 000 & 6.31 & 20.12 \\
\hline \multirow{3}{*}{$\begin{array}{l}\text { Synectic- } \\
\text { Low MB }\end{array}$} & Synectic- High MB & $-7,103$ & 2,738 &, 060 & -14.43 & 22 \\
\hline & Reciprocal-High MB &,- 139 & 2,826 & 1.00 & -7.70 & 7.42 \\
\hline & Reciprocal-Low MB & 6,111 & 2,881 &, 163 & -1.60 & 13.82 \\
\hline \multirow{3}{*}{$\begin{array}{l}\text { Reciprocal- } \\
\text { High MB }\end{array}$} & Synectic- High MB & $-6,964 *$ & 2,522 &, 041 & -13.71 &,- 22 \\
\hline & Synectic- Low MB &, 139 & 2,826 & 1.00 & -7.42 & 7,70 \\
\hline & Reciprocal-Low MB & 6,250 & 2,676 &, 106 &,- 91 & 13.41 \\
\hline \multirow{3}{*}{$\begin{array}{l}\text { Reciprocal- } \\
\text { Low MB }\end{array}$} & Synectic- High MB & $-13,214 "$ & 2,583 &, 000 & -20.12 & -6.31 \\
\hline & Synectic- Low MB & $-6,111$ & 2,881 &, 163 & -13.82 & 1.60 \\
\hline & Reciprocal - High MB & $-6,250$ & 2,676 &, 106 & -13.41 &, 91 \\
\hline
\end{tabular}

*. The mean difference is significant at the 0.05 level. 
is as follows:

Based on Table 4, an explanation of the Tukey Test can be given. The explanation

1) Based on the results of the Tukey test, it can be concluded that there is a significant difference between the creative thinking abilities of students who are taught with the synectic model and have a high learning interest compared to the creative thinking skills in writing free poetry of students who are taught with the reciprocal model and have high MB (mean Diff $=6.964$; significant $=0.041$ )

2) Based on the results of Tukey's test, it can be concluded that there is a significant difference between the ability to think creatively in writing free poetry of students who are taught with the synectic model and have a high MB compared to the ability to think creatively in writing free poetry of students who are taught using the reciprocal model and have an interest in learning. Low (Mean Diff $=13,214$; significant $=0,000$ )

\subsection{Discussion}

The initial condition of students' creative thinking ability in writing poetry in the experimental group and the control group was known by doing a pretest to write poetry. The pretest activities of both the control group and the experimental group were held in the form of writing poetry individually. At the time of the pretest, most of the students had written poetry with elements of imagery, content and message that matched the theme. However, it is still lacking in the use of elements of diction, language style and interesting sounds. At the time of the pretest, most of the students in group A and group B did not really understand the elements of rhyme or sound. Important rhymes or sounds are included in poetry to beautify and give an unusual poetic impression to a work. This element is less visible in most student works.

Based on the results of statistical calculations with the help of SPSS version 23, the highest score achieved by the control group at the pretest was 75 and the lowest score was 40 with a mean score of 57,61 , a median score of 60 , and a mode score of 60 . the experimental group was 70 and the lowest score was 45 with a mean score of 60.65 , a mode score of 60 , and a median score of 60.00 . The results of these statistical calculations indicate that students' creative thinking skills in the control group and the experimental group have no significant difference between the two groups. This shows that both groups have the same initial skills to write poetry.

Based on the posttest results in both groups, it can be described that the class language used by the two groups is the same, namely using hyperbolic language which causes exaggeration effects in poetry. The images used are the same, namely visual images. Students in the experimental group were richer in diction than students in the control group. The rhyme or sound that the students of the experimental group put up at the end of the sentence of each line is able to clarify expressions, create aesthetic effects and evoke responses to the reader's thoughts and feelings. The repetition of the word mum and their repetition in the work of the control group students was sufficient to have an effect on word emphasis, but it did not beautify the poetry. The mandate that appears in the poetry of the experimental and control groups is equally an interesting ending to the poetry. In the building blocks of poetry in the form of meaning or content, both groups are in accordance with the theme, but the experimental group is more interesting and able to describe and reflect feelings.

Based on the analysis of the poetry content of one of the students in group A, it can be described that the poetry made uses a lot of diction and appropriate language, according 
to the expressions expressed, solid and rich in meaning. This poem illustrates that students in the experimental group are able to analogize poverty-themed videos with their daily lives. This poetry uses repetition figures. Repetition is a figure of speech in the form of repetition of words as an affirmation. The diction used in this poem is also a choice of words that are not usually used in everyday language. The reader can feel poetic impression. The tone of the sound produced in this poem is attractive and has a beautiful effect. The mandate in this poem can the reader feel both expressly and implicitly. The message is that all people must fight so as not to be oppressed by poverty. Although not so rich in imagery, this poetry is rich in diction and captivating language. On the other hand, poetry by control group students with the same sub-theme creates less rich diction and class language in their poetry. The poetic and interesting figurative language is not emphasized in this poetry. Group B students tend to use everyday language.

\section{Conclusion}

Based on the results of research and discussion, several conclusions can be drawn including the following:

1. There is a significant difference between the ability to think creatively in writing free poetry of students taught with the synectic model compared with the average thinking ability of students who are taught in writing free poetry with the reciprocal model $\left(\mathrm{F}_{\text {count }}=11.664\right.$ and sig. $\left.0.001<0.05\right)$.

2. The average creative thinking ability in writing free poetry of students who have high learning interest is higher than the average ability to think creatively in writing free poetry of students who have low learning interest $\left(\mathrm{F}_{\text {count }}=12.165\right.$ and sig. $0.001<0.05)$.

3. There is an interaction between learning models and interest in learning in influencing students' creative thinking skills in writing free poetry $\left(\mathrm{F}_{\text {count }}=7.054\right.$ and sig. 0.011 $<0.05)$.

\section{References}

Anggraeni, Krisna. 2017. Efektivitas Model Menulis Kolaborasi Dengan Media Big Book Terhadap Keterampilan Menulis Kreatif. Jurnal Cakrawala Pendas. 3(2): 1-10.

Djaali. 2008. Psikologi Pendidikan. Jakarta: Bumi Aksara.

Joyce, Bruce.,dkk. 2009. Models of teaching. New Jersey: Pearson Education Inc.

Mutmainnah Ummi. 2016. Penerapan Model Sinektik Terhadap Kreatifias Belajar Siswa Pada Mata Pelajaran Ilmu Pengetahuan Alam Kelas V Di Madrasah Ibtidaiyah Hijriyah Ii Palembang. Jurnal ilmiah PGMI. 2(1)

Nazila, D.K., Adisaputera, A., and Saragih, A. (2020). Development of Teaching Material for Short Story Writing Experience Based on 7th Grade Students of Junior High School 2 Kejuruan Muda. Budapest International Research and Critics in Linguistics and Education (BirLE) Journal Vol 3 (2): 1137-1150.

Saragih, J.Y., Adisaputera, A., and Saragi, D. (2019). The Effect of Reasoning Skills on Writing of Explanation Text Assessed from the Social Economic Status of Parents in Class VIII, SMP Negeri 2 Raya, Simalungun District, Indonesia. Budapest International Research and Critics in Linguistics and Education (BirLE) Journal Vol 2 (3): $78-87$.

Siddiqui, M.H. 2013. synetics model of teaching: developing creativityskills of individuals and groups of society. Indian Journal of Applied Research. 3(4) 
Slameto. 2010. Belajar dan Faktor-Faktor yang Mempengaruhinya. Jakarta: PT. Rineka Cipta.

Trianto.2013. Model Pembelajaran Terpadu Konsep, Strategi, Dan Implementasinya Dalam Kurikulum Tingkat Satuan Pendidikan (KTSP), Jakarta: Bumi Aksara.

Yusrizal, Y., \& Fatmawati, F. (2020). Pengaruh Model Reciprocal Teaching dan Kecerdasan Intrapersonal terhadap Hasil Belajar IPS Siswa. Jurnal Tematik, 10(2), 90-95.

Yusrizal, Y., Hajar, I., \& Tanjung, S. (2019). Analysis of Elementary School Teachers' Ability in Using ICT Media and Its Impact on the Interest to Learn of Students in Banda Aceh. Budapest International Research and Critics in Linguistics and Education (BirLE) Journal, 2(3), 45-57. 